\title{
Water Resource Management in a Hard Rock Terrain for Sustaining Irrigated Agriculture - A Case Study of Jharkhand, India
}

\author{
S. P. Singh and R. A. K. Verma
}

\begin{abstract}
India has $15 \%$ of the world population but only with $2 \%$ of the land area and $4 \%$ of world water supply. In Jharkhand only about $21 \%$ of total ground water and surface water is being utilized for irrigation, industry and other municipal uses. Therefore, the integrated water management is vital for sustainable economic development. Availability of water is under stress to meet the requirements in various sectors. The quality of water also plays an important role for irrigation purpose. Various norms have been prescribed for suitability of ground water for irrigation purpose.
\end{abstract}

Index Terms-Hard rock terrain, Jharkhand, sustainable development, water management.

\section{INTRODUCTION}

Water is a precious natural resource, a basic human need and prime national asset. The extent to which water is plentiful or scarce, clean or polluted, beneficial or destructive, influence the quality of human life. The total resource available is 240 B.C.M. of surface water along with the ground water recharge every year. It would be 430 B.C.M. of water every year. If we add both the surface \& ground water our Resource is excess in demand.

Now the question arises where have we gone wrong? The answer depends upon the recent Techniques and Management Strategies applied in water resource management.

\section{Methodology}

The study is based upon the primary observations and researches conducted by the authors and review of literatures. Mostly secondary data sources have been used to understand the water management issues of the concerned area.

\section{GRound Water DeVelopment IN Hard Rocks}

From the hydro-geological point of view the hard rock are those lithological units which lack primary porosity. All the igneous and metamorphic rocks namely granite, gneisses, schists, khondalites, dolerites, gabbro, basalt etc. can be grouped in this category "unpublished" [1]. The water

Manuscript received October 30, 2014; revised January 10, 2015.

S. P. Singh and R. A. K. Verma are with Institute of Science \& Management (I.S.M.), ISM Campus, Ranchi, Jharkhand, PIN-834004 India (e-mail: sureshprasad_singh@yahoo.co.in, ismr.rakverma@gmail.com). bearing capacity of these rocks depend on their ability to develop the secondary porosity which depends on the nature and extent of geological, structural and tectonic processes. Consequently, a high degree of variations are seen even within a given rock type. This is why the hydraulic properties of the hard rocks are very complex. The development of secondary porosity in hard rocks is controlled by lithology, tectonics and climates.

Weathering also enhances the porosity of the rock formation. These processes generally convert the massive rock into a granular rock. In any hard rock terrain generally two types of zones are recognized. The first one is the weathering rock mantle near the ground surface which occurs as more or less a granular material. Here, the porosity is inter-granular and this zone behaves like a granular aquifer medium. This zone underlain by the bed rock where the fracture porosity is the controlling factor. This zone is generally unaltered and devoid of water bearing capacity. However, the network of horizontal and vertical joints and fracture make up the aquifer system.

\section{A CASE STUDY OF JHARKHAND}

The state of Jharkhand is plateau region with geographical area of $79.714 \mathrm{Sq}$. Km with 2.60 Crore population. The state is endowed with vast natural resources viz. Mineral resources, Water resources, Forest resources, etc. The state lies between latitude $21^{\circ} 58^{\prime}$ to $25^{\circ} 18^{\prime} \mathrm{N}$ to longitude $83^{\circ} 22^{\prime}$ to $87^{\circ} 58^{\prime}$ East. Its capital Ranchi is located on line of Cancer (lat. $23^{\circ} 30^{\prime} \mathrm{N}$ ). The area and population of state are $2.4 \% \& 2.6 \%$ of the country respectively. After creation of the state water scarcity is increasing as additional people are staking their claims to the water resources of the region. The manifestation of water scarcity is reflected in some of the dry rivers. Over pumping of ground water is common in some parts of Jharkhand, specifically in key food producing regions. The falling watertable due to over pumping is an important phenomenon witnessed in some parts of the state. The water table is falling at the rate of $0.4 \mathrm{~m} /$ year (Table I), forcing people to bore deeper and deeper. The recharge of aquifers is negligible as compared to extraction of water. Due to loss of Topsoil of cropland, the food security is at risk. The cropland is decreasing due to construction of factories, roads in urban areas. Soil erosion is a common phenomenon resulting in decrease in agricultural production. The rapid industrialization and urbanization of the state have increased demand for water resources for industrial, agricultural and municipal uses. It is therefore imperative that the potentiality of water resources is deciphered so that this 
precious natural resource can be judiciously used for improving socio-economic condition in this state of Jharkhand.

TABLE I: FALL OF UNDERGROUND TABLE IN JHARKHAND

\begin{tabular}{|c|c|}
\hline Ranchi & 52 feet \\
\hline Jamshedpur & 56 feet \\
\hline Godda & 61 feet \\
\hline Dhanbad & 50 feet \\
\hline Chas & 51 feet \\
\hline Giridih & 49 feet \\
\hline Palamu & 48 feet \\
\hline Chatra & 47 feet \\
\hline Pakur & 48 feet \\
\hline Simdega & 10.6 meters \\
\hline Gumla & 13.8 meters \\
\hline Lohardaga & 11.7 meters \\
\hline Hazaribagh & 12.3 meters \\
\hline Singhbhum & 13.8 meters \\
\hline Bokaro & 12.1 meters \\
\hline Dumka & 11.8 meters \\
\hline Jamtara & 12.5 meters \\
\hline
\end{tabular}

TABLE II: IRRIGATION STATUS OF JHARKHAND

\begin{tabular}{|c|c|c|}
\hline Sl. No. & District & $\begin{array}{c}\text { Percentage of Irrigated land } \\
\text { of Total Agriculture Land }\end{array}$ \\
\hline 1. & Godda & 14.21 \\
\hline 2. & Dumka & 9.47 \\
\hline 3. & Sahebganj (Pakur) & 3.86 \\
\hline 4. & Deoghar & 14.22 \\
\hline 5. & Dhanbad (Bokaro) & 2.08 \\
\hline 6. & Hazaribagh (Chatra) & 10.51 \\
\hline 7. & Giridih & 6.99 \\
\hline 8. & Palamu (Garhwa) & 24.25 \\
\hline 9. & Ranchi & 6.12 \\
\hline 10. & Lohardagga & 8.87 \\
\hline 11. & Gumla & 2.45 \\
\hline 12. & E. Singhbhum & 5.0 \\
\hline 13. & W. Singhbhum & 4.0 \\
\hline
\end{tabular}

\section{GEOLOGY OF JHARKHAND}

The 28th State of India constitutes a part of Indian peninsular shield - a stable cratonic block of earth crust. The major portion of the state stand on a hard rock of granite gneiss of archaen age is predominant in the area. The more resistant among them are exposed on the surface as hills. The Chotanagpur Plateau represents a vast area from western part of Bihar to the border of West Bengal in the east. Physiographically, the plateau has been divided into following two parts:

1) Ranchi Plateau

2) Plateau

The Ranchi plateau has flat to undulating topography with occasional ridges. This plateau gradually slopes down towards SE in the hilly regions of Singhbhum. The most important lithological unit comprise Archean Metamorphites with associated intrusives and sedimentaries belonging to
Gondwana Supergroup and their associated rock. The Vindhyan Limestone and shales are also present in NW part of the state. The Rajmahal hills in NE extremeties of Jharkhand are made up of Jurassic Volcanic flows \& intertrappians. The tertiary laterites, bauxites and lithomarge present in some parts of the area.

\section{Availability of Water Resource and Drainage}

The annual rainfall in this region varies between 800 to $1800 \mathrm{~mm}$, the average being $1300 \mathrm{~mm}$, but their regional distribution is highly variable on account of the disposition of hill ranges. The Eastern \& NW of the state gets lesser rain and as they fall under rain shadow area. Topographically it is collage of sub-plateaus which are characterized by steep slopes to rolling relief. These Geomorphic configurations create more surface rain off in very short duration. The climate is moderate; however, the temperature goes as high as $43^{\circ} \mathrm{C}$ at few places during summer. The rainfall, the topography, hill slopes, forest and waste lands cause greater percentage of surface flow. The geology and Geohydrological features do not permit heavy infiltration of rainfall because of hard rock terrain "unpublished" [2]. The natural recharging of ground water is only about $10-12 \%$ of the surface flow. The state of Jharkhand has 12 major river basins and other small streams draining outside the state "unpublished" [3].

The total available surface water in Jharkhand state is 23789 MCM out of which only 4777 MCM of water is being utilized for irrigation, drinking water and industries. The total ground water available in the state is $4992 \mathrm{MCM}$ out of which only $1328 \mathrm{MCM}$ water is being utilized for different purposes. Thus total surface and ground water unutilized is 23677 MCM. Thus we are utilizing only $21.20 \%$ of total water resources at present.

It is essential to utilize the $78.8 \%$ of unutilized water. The state of Jharkhand is drained by seven major river system viz. Subarnrekha, South Koel, North Koel, Damodar, Sankh, Ajay \& Mayurakshi, besides other streams. There are number of drainage axes, sharp and well defined. The major rivers namely Damodar, Subarnrekha, South Koel and Sankh etc. moving roughly in SE direction and discharge their waters in Bay of Bengal. The rivers are mainly rainfed. There is little seepage of ground water in hard rock terrain. However, the high gradients of streams ensure quick discharge of surface flow. The following drainage patterns are present in the region - Dendritic, pinnate, radial, barbed \& parallel.

\section{HYDROGEOLOGICAL SET-UP}

Ground water development in hard rock terrain is of special importance. The various geological formation presents different ground water conditions in the area. The search for ground water, its development and management is a serious problem to be reckoned with. Hydrogeologically, the entire area of Jharkhand can be divided into following two parts: (a) Hard rock areas \& (b) Soft rock areas. For a detailed knowledge of groundwater resource, it is essential to know the following features:

1) Nature and extent of aquifers

2) Depth 
3) Form \& slope of water table

4) Recharge and discharge of ground water in relation to lithology. The Geomorphic setting and chemical characters of ground water.

Ground water in the area is replenished mainly by the atmospheric precipitation. The ground water is generally not enriched by seepage of river water because rivers are effluent in nature. The depth of water table and the fluctuation depends on:

1) Rainfall

2) Geomorphological features

3) Lithology

During the period of rainfall the fluctuation of water table is observed in some of the area. The ground water occurs in hard and crystalline rock, laterites and riverine sands. About $80 \%$ of area of Jharkhand is covered by hard crystalline igneous and metamorphic rocks of Precambrian age. In majority of cases the hard rock form the acquifers. However, in some areas laterites and reverine sands form good aquifers near the river bank. The Archean and Precambrian which almost occupy the entire area are of very low porosity due to compactness and consolidated nature as such permeability is very low.

However, appreciable porosity and permeability are developed through formation of secondary porosity by fracture, fissures, joints and weathering of the rocks.

The fractures and joints form the passage for the movement of ground water and act as reservoir of ground water also. Summarily it can be concluded that the ground water in the area is controlled by the following factors:

1) Topographical setting

2) Thickness of weathered zone

3) Extent, size, openness and interconnections of joints and fractures.

\section{A. Sustainability of Irrigated Agriculture in Jharkhand}

India has $15 \%$ of the world population but only with $2 \%$ of the land area and $4 \%$ of world water supply. In Jharkhand only about $21 \%$ of total ground water and surface water is being utilized for irrigation (Table II), industry and other municipal uses. Therefore, the integrated water management is vital for sustainable economic development. Availability of water is vital for sustainable economic development. Availability of water is under stress to meet the requirements in various sectors. The quality of water also plays an important role for irrigation purpose. Various norms have been prescribed for suitability of ground water for irrigation purpose (Table III, IV and V).

\begin{tabular}{|c|c|c|c|}
\hline Parameter & $\begin{array}{l}\text { Generally } \\
\text { Acceptable }\end{array}$ & $\begin{array}{l}\text { Relaxation for special } \\
\text { planned } \\
\text { (Exceptional Notified } \\
\text { Cases) }\end{array}$ & Note \\
\hline Conductivity $\mu \mathrm{mhos} / \mathrm{cm}$ & $<2250$ & $<4000$ & $\begin{array}{l}\text { The irrigation water having conductivity more than } 2250 \mathrm{us} / \mathrm{cm} \text { at } 25^{\circ} \mathrm{C} \text { may } \\
\text { reduce vegetative growth and yield of the crops. It may also increase soil } \\
\text { salinity which may affect its fertility. }\end{array}$ \\
\hline $\begin{array}{l}\text { Faecal Coliform } \\
\text { MPN/100ml }\end{array}$ & $<5000$ & & No limit for irrigating crops which is not eaten raw \\
\hline $\mathrm{PH}$ & $6-9$ & & Soil Characteristics important \\
\hline $\begin{array}{l}\text { Biochemical Oxygen } \\
\text { Demand, mg/1 }\end{array}$ & $<100$ & & $\begin{array}{l}\text { Land can absorb organic matter faster than water; however, the conditions of } \\
\text { water logging should be avoided. Stagnant water should not persist for more } \\
\text { than } 24 \text { hours. }\end{array}$ \\
\hline $\begin{array}{l}\text { Floating materials such as } \\
\text { wood, plastic, rubber }\end{array}$ & Absent & & May inhibit water percolation \\
\hline Boron, mg/lt. & $<2$ & & $\begin{array}{l}\text { Boron is an essential nutrient for plant growth, however it becomes toxic } \\
\text { beyond } 2 \mathrm{mg} / \mathrm{lt} \text {. }\end{array}$ \\
\hline SAR & $<26$ & & $\begin{array}{l}\text { SAR beyond } 26 \text { may cause salinity and sodicity in the soil. When it exceeds } \\
\text { the limit, the method of irrigation and salt tolerance of crops should be kept } \\
\text { in mind. }\end{array}$ \\
\hline Total Heavy Metals mg/lt. & $<0.5$ & $<5.0$ & \\
\hline
\end{tabular}

TABLE IV: IRRIGATION WATER SHEDS

\begin{tabular}{|c|c|c|}
\hline \multirow{2}{*}{ Parameter } & Category & Water Character \\
\hline Electrical & $<250$ & Excellent \\
Conductivity & $250-750$ & Good \\
us/cm & $750-2000$ & Permissible \\
& $2000-3000$ & Unsuitable \\
\hline & $<20$ & Excellent \\
Sodium (Na) & $20-40$ & Good \\
& $40-60$ & Permissible \\
& $60-80$ & Doubtful \\
& $>80$ & Unsuitable \\
\hline SAR(Sodium & $<10$ & Excellent \\
Absorption & $10-18$ & Good \\
Ratio) & $18-26$ & Fair \\
& $>26$ & Poor \\
\hline RSC (Residual & $<1.25$ & Safe \\
Sodium & $1.25-2.5$ & Marginal \\
Carbonate) & $>2.5$ & Unsuitable \\
\hline
\end{tabular}

TABLE V: SALINITY HAZARD OF IRRIGATION WATERS

\begin{tabular}{|c|c|c|}
\hline$\underline{\text { Class }}$ & $\underline{\underline{\mathbf{E c}(\mathbf{i n}}}$ & $\underline{\underline{\mathbf{u s m}} \mathbf{c o m m e n t s}}$ \\
\hline $\mathrm{C} 1$ & $<250$ & $\begin{array}{c}\text { Low salinity water can be used in most } \\
\text { soil and crops }\end{array}$ \\
\hline $\mathrm{C} 2$ & $250-750$ & $\begin{array}{c}\text { Medium salinity water can be used in } \\
\text { moderately leaching Soils and soil } \\
\text { tolerant crops }\end{array}$ \\
\hline C3 & $750-2250$ & $\begin{array}{c}\text { High salinity water: can be used in high } \\
\text { salt tolerant crops and are unsuitable for } \\
\text { soil with restricted drainage }\end{array}$ \\
\hline C4 & $2250-5000$ & $\begin{array}{c}\text { Very high salinity water: not suitable for } \\
\text { irrigation under Ordinary conditions }\end{array}$ \\
\hline
\end{tabular}

Various chemical constituents that affect the suitability of water for irrigation are as under:

1) Total concentration of soluble salts

2) Relative proportion of sodium to calcium and 
magnesium

3) Concentration of boron and

4) The relative proportion of bicarbonate to calcium and magnesium

The suitability of groundwater for irrigation is also related to nature and composition of the soil and sub-soil, climate, type of crop etc. The total dissolved solids content, measured in terms of specific electrical conductance gives the salinity hazard of irrigation waters. According to United State Salinity Laboratory, the salinity can be grouped in 4 classes.

Besides salinity hazard, excessive sodium content in water makes it unsuitable. The sodium hazard in irrigated water is expressed by determining the Sodium Absorption Ratio (SAR) by the relation:

$$
\mathrm{SAR}=\frac{\mathrm{Na}}{\frac{\sqrt{(\mathrm{Ca}+\mathrm{Mg})}}{2}}
$$

In which the concentrations are expressed in milli equivalents per litre. The general guidelines are:

- Low sodium water $S_{1}$ having $S A R<10$

- Medium sodium water $\mathrm{S}_{2}$ having SAR 10-18

- High sodium water $S_{3}$ having SAR 18-26, and

- Very high sodium water $\mathrm{S}_{4}$ having $\mathrm{SAR} / 26$

Some of the water samples of the area belong to C1 S1, $\mathrm{C} 2 \mathrm{~S} 1$ and C2S2 categories. Majority of the water samples belong to $\mathrm{C} 3 \mathrm{~S} 1$ and $\mathrm{C} 3 \mathrm{~S} 2$ categories, indicating high salinity water which can be used in the soils having adequate drainage facility and plants with good salt tolerance should be selected for cropping in the area "unpublished" [4].

\section{B. Water Resource \& Management}

Rapid industrialization and urbanization in Jharkhand have increased the demand of water in all spheres. We are utilizing only $21.20 \%$ of total water resources at present and rest $78.8 \%$ remains unutilized. Therefore, the conservation and efficient water resource management is essential. The management and reuse of irrigational water will adequately help water resource management in Jharkhand. In the hilly area, where the slope is high the plantation of green vegetation is required. The conservation of water by optimum surface and ground water development without wastage is required. To enhance the natural supply the recharge is also required in the following manner [5]:

1) Artificial recharge by Basin Stream Channel, ditch \& furrow, pit method

2) Construction of check dams, Recharge well in suitable areas

3) Rain harvesting techniques should be applied in townships and rain shadow zone.

\section{Recommendations for Water Resource Management in Jharkhand}

1) Identification of water scarce area

2) Development of water shed area

3) Study of soil type

4) Recycling of used water

5) Assessment of water requirement in industries and Agriculture
6) Identification of Recharge discharge area

7) Identification of potential aquifer zone

8) Study of secondary porosity in hard rock

9) The sedimentation of major river basis and possibility of disilting should be explored

\section{Geological Intervention}

1) An integrated geological investigation programme taking into account, the lithology and structure as the first leveled base data.

2) Disposition of hill ranges and slope studies should be given due consideration.

3) The weathered mantle specialty the lateritic zone should not be excavated for road materials as these are the most important litho unit for conservation of rain water.

4) The Remote Sensing Data should be utilized in land zonation planning and GPS \& GIS be employed to form an integrated mode of management of water resources.

\section{CONCLUSION}

The availability of requisite water quality is under stress to meet the requirements in Agriculture Sector in Jharkhand. Various norms have been prescribed for suitability of ground water for irrigation purposes. Taking into consideration the various water quality criteria for irrigation purposes viz. Sodium absorption ratio, total Boron content, Electrical Conductivity, BOD, Residual Sodium Carbonate, Soil Characteristics etc, the plants with good salt tolerance should be selected for cropping in Jharkhand state in India.

\section{REFERENCES}

[1] S. P. Singh, "Petrochemistry of the granites and the associated rocks north of Latehar District-Palamou, Bihar," PhD. Thesis, Ranchi University, Ranchi, 1981.

[2] S. P. Singh, B. Singh, and U. Kumar, "Water management strategy for achieving food security," in Proc. ICESD-2013, Dubai, UAE, 2013.

[3] B. Kumar, "Hydrogeological and geochemical studies of the Area around Hazaribag, Bihar," PhD. Thesis, Vinoba Bhawe University, Hazaribag, 2001.

[4] R. Kumar, "Hydrological investigations in the industrial area of Ranchi District, Bihar, with special reference to pollution of ground water resources," PhD. Thesis, Patna University, Patna, 2002.

[5] S. H. A. Khan, "Hydrogeology \& ground water resources development potential of Ranchi, Lohardaga and Gumla District," Bihar (C. G. W. B. Report), 1987.

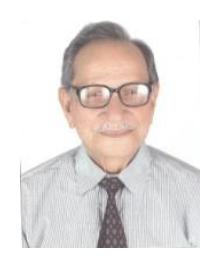

S. P. Singh was born on September 21, 1943. He served as the vice chancellor in V. K. S. University, Ara, Bihar, India from 1996 to 1099 . He worked as a professor and the head from 2002 to 2003 in the Dept. of Geology, Ranchi University, Ranchi, Jharkhand, India. At present, he is serving as a professor and the chief advisor in Institute of Science \& Management, Ranchi, Jharkhand, India.

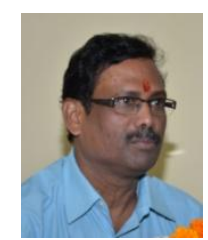

R. A. K. Verma was born on January 6, 1957. He is one of the founder members of Institute of Science \& Management, Ranchi. He served as the director in Institute of Science \& Management, Ranchi, Jharkhand, India. At present he is the chairman of Institute of Science \& Management, Ranchi, Jharkhand, India. 